\title{
Isolating non-subduction-driven tectonic processes in Cascadia
}

\author{
K. A. McKenzie* ${ }^{*}$ and K. P. Furlong
}

\begin{abstract}
Several tectonic processes combine to produce the crustal deformation observed across the Cascadia margin: (1) Cascadia subduction, (2) the northward propagation of the Mendocino Triple Junction (MTJ), (3) the translation of the Sierra Nevada-Great Valley (SNGV) block along the Eastern California Shear Zone-Walker Lane and, (3) extension in the northwestern Basin and Range, east of the Cascade Arc. The superposition of deformation associated with these processes produces the present-day GPS velocity field. North of $\sim 45^{\circ} \mathrm{N}$ observed crustal displacements are consistent with inter-seismic subduction coupling. South of $\sim 45^{\circ} \mathrm{N}$, NNW-directed crustal shortening produced by the Mendocino crustal conveyor (MCC) and deformation associated with SNGV-block motion overprint the NE-directed Cascadia subduction coupling signal. Embedded in this overall pattern of crustal deformation is the rigid translation of the Klamath terrane, bounded on its north and west by localized zones of deformation. Since the MCC and SNGV processes migrate northward, their impact on the crustal deformation in southern Cascadia is a relatively recent phenomenon, since $\sim 2-3 \mathrm{Ma}$.
\end{abstract}

Keywords: GPS velocities, Cascadia subduction zone, Mendocino Triple Junction migration, Sierra Nevada-Great Valley block, Upper-plate deformation

\section{Introduction}

The development of dense, continuous GPS networks in subduction zones has provided key upper-plate displacement data that can be used to infer the nature of plate coupling along the megathrust interface. This subduction coupling signal is interpreted to be largely ephemeral, with upper-plate displacements recovered during slip events on the plate interface including both relatively regularly occurring episodic tremor and slip (Rogers and Dragert 2003; McKenzie et al. 2020) and infrequent but substantial megathrust earthquakes (Satake 2015; Moreno et al. 2018). In many subduction zones, for example along Middle America, this subduction coupling signal is overprinted by the effects of other tectonic processes; generating a hybrid signal that cannot directly be used to either constrain megathrust coupling or define

\footnotetext{
*Correspondence: kam724@psu.edu
}

Department of Geosciences, The Pennsylvania State University, University Park, PA, USA the effects of these non-subduction tectonic processes (LaFemina et al. 2009; Morell et al. 2012). Such a hybrid signal occurs along the Cascadia subduction zone (Fig. 1), where subduction coupling is overprinted by non-subduction tectonic processes, especially in southern Cascadia. In particular, associated with the NNW migration of the Mendocino Triple Junction (MTJ), the Mendocino crustal conveyor (MCC) produces crustal shortening, and associated crustal thickening and uplift in advance of the MTJ (Furlong and Govers 1999; Lock et al. 2006). This crustal deformation is geologically long-lived and, based on modeling, should extend several 100s of km beyond the MTJ. Inboard (east) of the MCC deformation, the Sierra Nevada-Great Valley (SNGV) block is also migrating northwestward (Dixon et al. 2000, Bennet et al. 2003) (at a substantially lower rate than the MTJ), with its motion impinging on the inboard regions of southern Cascadia (Fig. 1). The geographical extent of deformation associated with these two tectonic drivers is undefined, but in both cases, the deformational signal will be
Springer Open (c) The Author(s) 2021. This article is licensed under a Creative Commons Attribution 4.0 International License, which permits use, sharing, adaptation, distribution and reproduction in any medium or format, as long as you give appropriate credit to the original author(s) and the source, provide a link to the Creative Commons licence, and indicate if changes were made. The images or other third party material in this article are included in the article's Creative Commons licence, unless indicated otherwise in a credit line to the material. If material is not included in the article's Creative Commons licence and your intended use is not permitted by statutory regulation or exceeds the permitted use, you will need to obtain permission directly from the copyright holder. To view a copy of this licence, visit http://creativeco mmons.org/licenses/by/4.0/. 


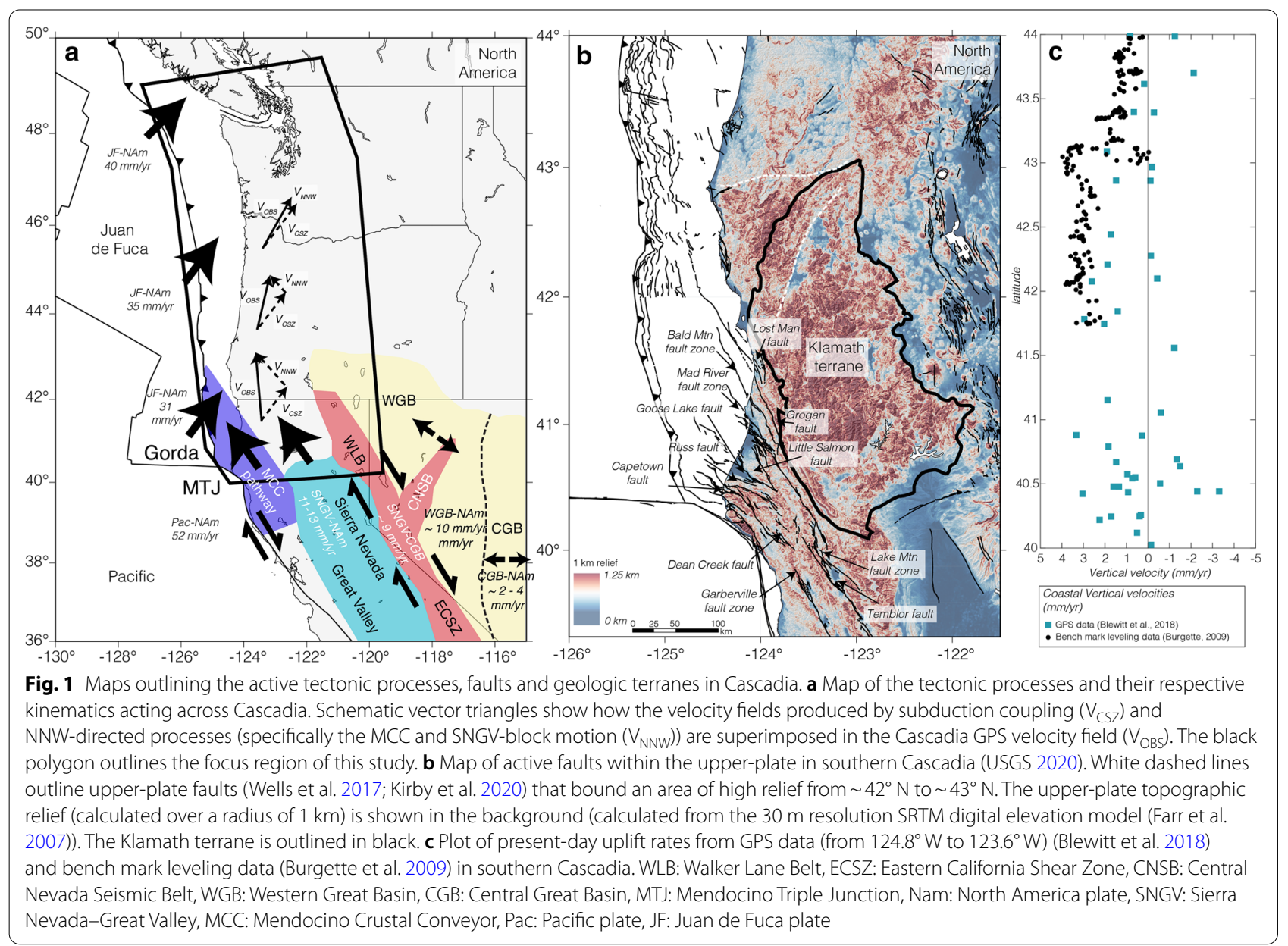

superimposed on the subduction coupling signal. In this study, we decompose the observed Cascadia GPS velocity field into its subduction-driven and non-subduction components and we analyze the non-subduction components to assess the tectonic effects of MCC and SNGV tectonics on the crust of southern Cascadia.

\section{Active tectonic processes deforming Cascadia}

In Cascadia, we see the expected NE-directed subduction coupling signal (with respect to stable North America) north of $\sim 45^{\circ} \mathrm{N}$ (Fig. 2). South of $\sim 45^{\circ} \mathrm{N}$, the GPS velocity field deviates from a subduction coupling displacement pattern, which precludes using a simple data inversion to infer subduction coupling (Additional file 1: Figure S1). South of the MTJ, observed GPS velocities reflect motion across the Pacific-(SNGV)-North America plate boundary system, directed to the NW$\mathrm{NNW}$. From immediately south of the MTJ to $\sim 45^{\circ} \mathrm{N}$, the directions of upper-plate velocities rotate smoothly from NNW (sub-parallel to the direction of San Andreas shear motion) to NE (sub-parallel to the direction of
Cascadia subduction convergence) (Fig. 2). Through our decomposition, we can assess if this clockwise rotation of GPS velocities in southern Cascadia can be the result of a superimposition of a MCC/SNGV driven NNWdirected velocity field (that is expected to decay in magnitude from south to north) onto a NE-directed velocity field (produced by subduction coupling). North of $\sim 45^{\circ}$ $\mathrm{N}$, since the effects of the MCC/SNGV driven deformation are likely quite small, the directions of upper-plate GPS velocities predominantly reflect subduction coupling, and fall within a $\sim 10^{\circ}$ range centered on the Juan de Fuca-North America relative plate motions (Fig. 2, Additional file 1: Table S1).

\section{Cascadia subduction}

Along the Cascadia subduction zone, the Juan de Fuca (and Gorda) plate(s) subducts obliquely beneath North America. This oblique convergence does not appear to partition into trench-parallel and trench-perpendicular components, as happens in some obliquely convergent subduction zones (Cashman et al. 1992; McCaffrey et al. 


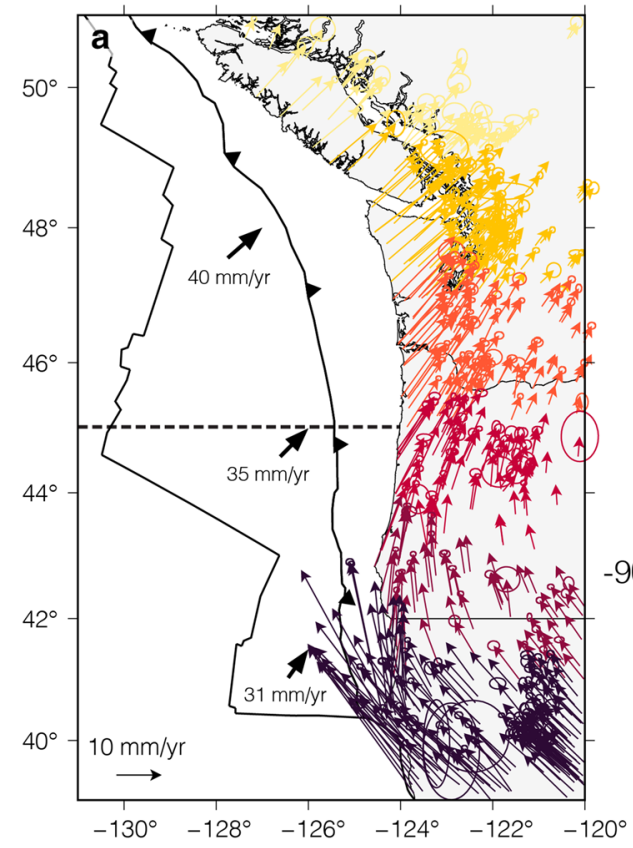

b

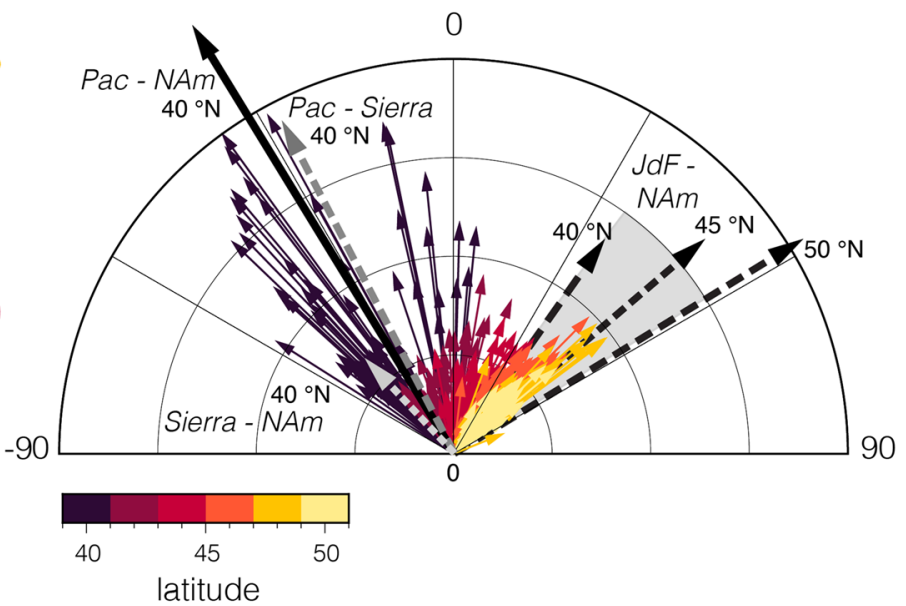

Fig. 2 a Continuous GPS velocity field (ellipses show 2 standard deviation uncertainties) in a stable North America reference frame, colored by latitude (Blewitt et al. 2018). The dashed line is the boundary at $\sim 45^{\circ} \mathrm{N}$ that separates the region to the north where the velocity field primarily reflects loading from Cascadia subduction coupling, from the region to the south where the velocity field reflects the superposition of subduction coupling with NNW-directed tectonic processes. $\mathbf{b}$ GPS velocities in $\mathbf{a}$, plotted on a half-rose diagram, colored by latitude. The relative motions of the Pacific-N. America, Pacific-SNGV, SNGV-N. America and Juan de Fuca-N. America plate/block pairs are shown. The Juan de Fuca-N. America relative motion changes with latitude. The shaded gray region shows the extent of directions represented by the NE (subduction) motions

2000; Manaker et al. 2008). Therefore, the expected signal of plate coupling on the subduction interface in Cascadia is NE-directed upper-plate shortening with larger displacements close to the trench that decrease with distance landward. This pattern is seen in the GPS data north of $\sim 45^{\circ} \mathrm{N}$, but is obscured in southern Cascadia (Fig. 2).

\section{Northward advance of the Mendocino Triple Junction via the Mendocino Crustal Conveyor}

The MTJ is migrating to the NNW at $50 \mathrm{~km} / \mathrm{Myr}$ with respect to North America (Furlong 1984; DeMets et al. 2010). Associated with this migration is NNW-directed (permanent) crustal shortening in advance of the MTJ, described by the MCC model (Furlong and Govers 1999; Furlong et al. 2003; Furlong and Schwartz 2004). North of the MTJ, the region of expected crustal shortening coincides with observed increases in crustal thickness (Beaudoin et al. 1996, 1998), geodetically-measured high uplift rates (Fig. 1; Blewitt et al. 2018; Burgette et al. 2009)), relatively high erosion and rock uplift rates, and relatively high elevations (Lock et al. 2006; Balco et al. 2013; Roering et al. 2015; Bennett et al. 2016). This crustal deformation can be seen in a NNW-striking surface displacement field that decays with distance north of the MTJ.

The footprint of shortening, based on the MCC model, should extend $\sim 200 \mathrm{~km}$ north of the MTJ, with the width of this deformation controlled by the geometry of the slab window ( 100-150 km wide (Furlong and Govers 1999; Furlong and Schwartz 2004)). The footprint of this NNWshortening will overlap with the NE-directed subduction earthquake cycle deformation in southwest Cascadia (Fig. 1).

Northward motion of the Sierra Nevada-Great Valley block Adjacent to (east of) the region of MCC deformation, the SNGV-block, a rigid microplate, translates to the NNW along the northern Eastern California Shear Zone-Walker Lane (nECSZ-WL) shear zones at 11-13 mm/year (Argus and Gordon 1991; Dixon et al. 2000; Plattner et al. 2010) relative to North America. The motion along the nECSZ initiated in the 12-6 Ma interval with significant northward motion of the SNGV beginning by $6 \mathrm{Ma}$ (McQuarrie and Wernicke 2005; Plattner et al. 2010). The northward motion of the SNGV block, similar to the MCC, will likely produce a NNW-directed shortening signal in southern Cascadia extending some distance to the north (Fig. 1). 


\section{Decomposition}

We decompose the present-day, observed GPS velocity field (Fig. 2) into two principle components: one directed to the NE (parallel to the Juan de Fuca-North America relative plate motions) and a second directed to the NNW (reflecting effects of the motion of the MTJ and the SNGV block with respect to North America) (Fig. 1). This separates the subduction component (largely recoverable over an earthquake cycle) from a NNW-directed geologic (shortening) component. Since Cascadia arc volcanism may also produce a signal recorded at some GPS stations, in our analysis, we do not use the GPS stations associated with volcanic centers.

\section{Decomposition methodology}

We define the direction of the subduction signal using the MORVEL Juan de Fuca-North America relative plate motions (DeMets et al. 2010), and treat the MCC and SNGV components in combination, since the direction of the SNGV block motion ( N50W (McCaffrey $2005))$ and the direction of the MTJ migration ( N60W (DeMets et al. 2010)) are approximately sub-parallel. We have tested the effects of using varying directions for the combination of these two NNW tectonic drivers, and find that the resulting component velocity fields are very similar (Additional file 1: Figure S2). As would be expected, SNGV-North America motion (McCaffrey 2005) better explains the observed GPS velocities east of $\sim 123^{\circ} \mathrm{W}$ (Fig. 3), and motions closest to the triple junction are better represented by a slightly more northerly directed motion (i.e., the Pacific-SNGV or PacificNorth America relative motions).

\section{Decomposition results}

Results of our GPS vector decomposition are shown in Figs. 3 and 4. The subduction coupling component of the GPS velocity field, typical of most subduction systems, is characterized by relatively high velocities at the coastline, closest to the trench, that decrease moving landward (Figs. 3b and 4a). The distance over which this decrease occurs, varies along the margin from north to south. NE-striking profiles (Fig. $4 \mathrm{a}$ ) in central Cascadia (at $\sim 44^{\circ}$ $\mathrm{N})$ show that the velocities decay to a background level of $\sim 2-4 \mathrm{~mm} /$ year, $\sim 300-350 \mathrm{~km}$ from the coastline (measured in the direction of relative plate motion), while further south, the velocities decay to $\sim 2-4 \mathrm{~mm} /$ year within $200 \mathrm{~km}$ landward of the coastline (Fig. 4a). North of $45^{\circ} \mathrm{N}$, the subduction field dominates and the decomposed subduction component comprises more

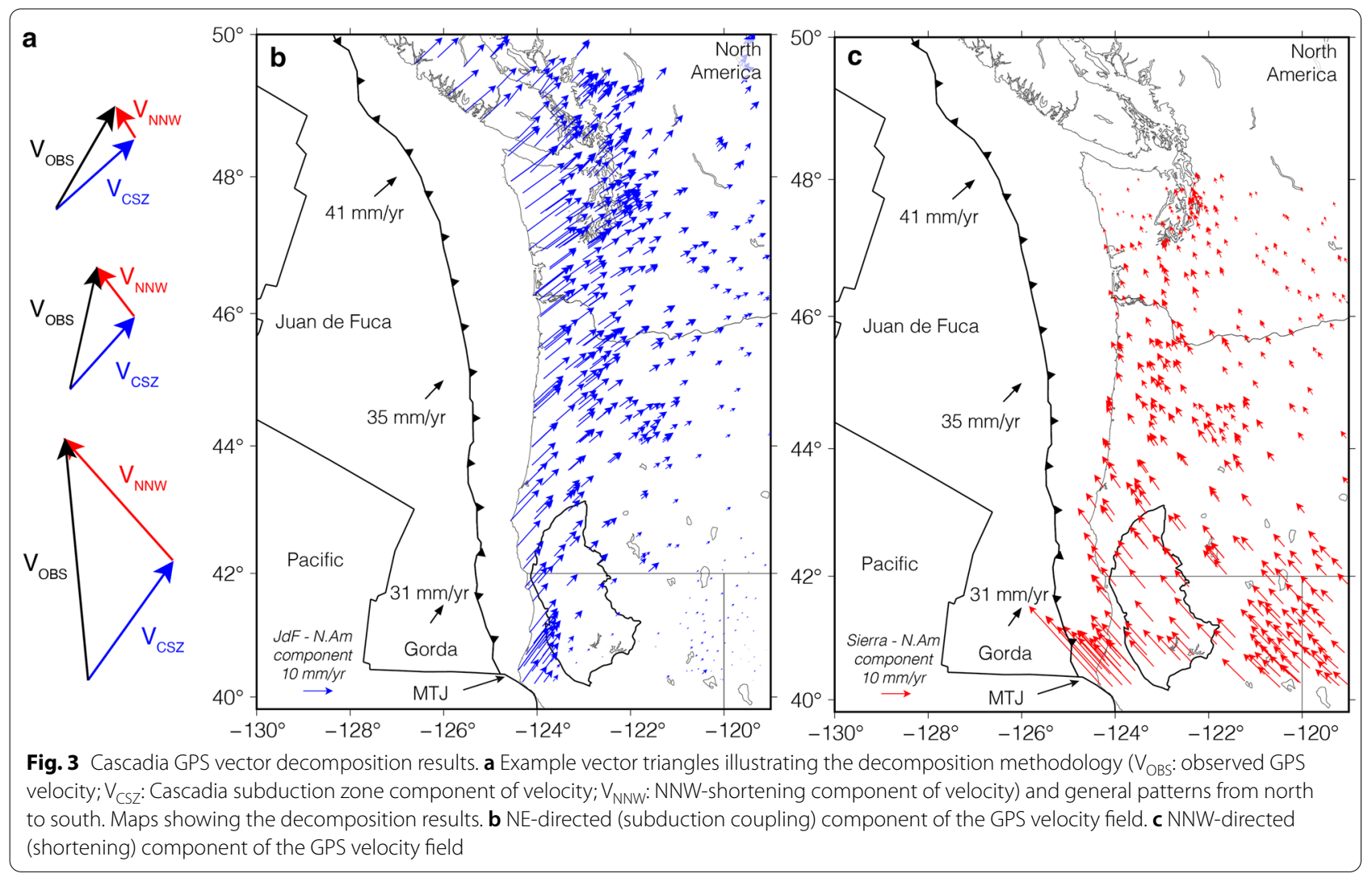



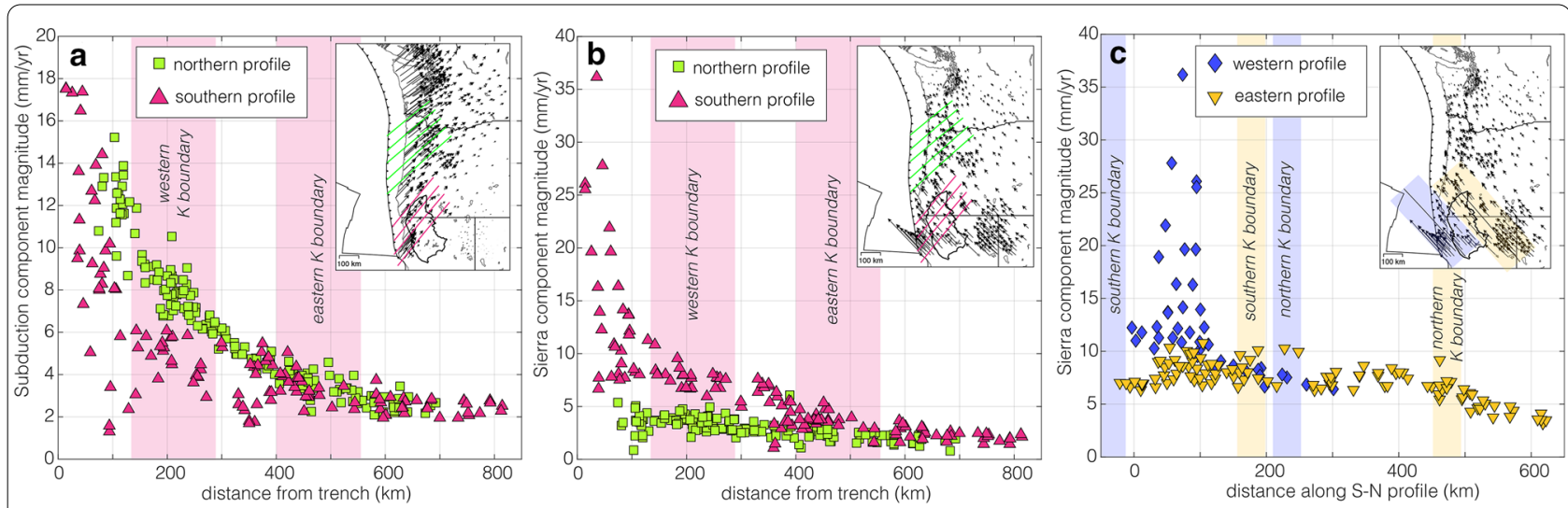

Fig. 4 Profile plots of the decomposed velocity components. The NE oriented ( $\mathbf{a}$ and $\mathbf{b}$ ) profiles project data within $25 \mathrm{~km}$ onto each profile, which are then combined. The NNW oriented profiles (c) project data within $100 \mathrm{~km}$ onto each profile. The maps in the right hand corner of each plot show the component of the GPS field the profile is sampling and the locations of each profile. a NE profiles through the subduction component of the GPS velocity field, $\mathbf{b}$ NE profiles through the NNW component of the GPS velocity field, $\mathbf{c}$ NNW profiles through the NNW component of the GPS velocity field. Shaded vertical bars in each graph show the approximate location of boundaries of the Klamath terrane, their colors corresponding to the profile they relate to

than $80 \%$ of the total GPS velocity field (Additional file 1: Figure S4).

The NNW component of the GPS velocity field, which decreases from south to north, is $5 \mathrm{~mm} /$ year or greater to $\sim 44^{\circ} \mathrm{N}$, approximately $400 \mathrm{~km}$ north of the MTJ (Fig. 4c). North of this, the NNW component decreases to $\sim 2 \mathrm{~mm} /$ year or less by $47^{\circ} \mathrm{N}$ (within the uncertainty of our analyses) (Fig. 4b). NNW-striking and NE-striking profiles through this component of the velocity field reveal details of the footprint of the MCC and SNGV components of the velocity field (Fig. 4). A NNWdirected profile in southwest Cascadia (where velocities are dominated by MCC effects), records a steep decrease in the NNW component over $\sim 50 \mathrm{~km}$. This suggests relatively high NNW-directed shortening in southwest Cascadia west of the Klamath terrane (immediately north of the MTJ). East of this, a second NNW profile shows that, in contrast, within the Klamath terrane, velocities are relatively constant, at $\sim 8-12 \mathrm{~mm}$ /year; implying the upper plate (Klamath terrane) is behaving relatively rigidly (Fig. 4c and Additional file 1: Figure S3). Similarly, NE profiles in southern Cascadia show relatively constant velocities across the Klamath terrane (Fig. 4b and Additional file 1: S3). However, to the west of the Klamath terrane, these NE profiles record a distinctive decrease in velocities from $\sim 35 \mathrm{~mm} /$ year to $\sim 10 \mathrm{~mm} /$ year over $\sim 200 \mathrm{~km}$ (Fig. 4b). To the east of the (rigid) Klamath terrane, along these NE profiles, velocities decrease again reaching $<5 \mathrm{~mm} /$ year (Figs. 4b, 4c, Additional file 1: S3). In northern Cascadia, NE profiles through the NNW component (at $\sim 44^{\circ} \mathrm{N}$ ) show a gradual decay from $5 \mathrm{~mm} /$ year to $1 \mathrm{~mm}$ /year or less over $500 \mathrm{~km}$ from the coastline (Fig. 4b).

\section{Discussion \\ Rigid versus deformable upper plate}

Our results show that the upper-plate displacements/ velocities (recorded by GPS data) in Cascadia can be described by the combination of an ephemeral subduction coupling signal and NNW-directed deformation produced by non-subduction tectonic processes (Figs. 3 and 4) - the advance of the MCC (Furlong and Govers 1999) and the SNGV block (Dixon et al. 2000). These non-subduction tectonic processes, unlike subduction coupling, produce significant, long-lived deformation in southern Cascadia. In some previous studies, the observed GPS data (north of $\sim 41^{\circ} \mathrm{N}$ ) have been alternatively interpreted as representing the superposition of the subduction coupling signal with an upper-plate that is acting as a rigid rotating block (or blocks) (i.e., Wells et al. 1998; Savage et al. 2000; McCaffrey et al. 2000, 2007, 2013; McCaffrey 2005). The assumption of a rotating, rigid upper plate implies little internal deformation in Cascadia, except that associated with subduction coupling and along block boundaries. We have compared our GPS decomposition results to the results of GPS decompositions that assume an upper-plate block rotation (specifically the single block model (m01r) and the multi-block model (m05G) from McCaffrey et al. (2007)). In our analyses, as described in the "Decomposition methodology" section, we assumed the direction of the subduction velocity field and the direction of MCC/SNGV velocity fields. We then decomposed the observed GPS velocity field into these 
two assumed directions and, thus, the magnitude of each component is defined by the observed GPS (non-decomposed) velocities (Fig. 3a). In the various rotating block models, in contrast, both the direction and magnitude of the rotation velocity in each block are determined by rotation poles. The subduction component in these models, that assume rigid block rotations, is then the difference between the rigid rotations (calculated from each block's pole of rotation) and the observed GPS. One consequence of this approach is that the azimuth of the subduction component varies with location and often differs significantly $\left(\sim 20^{\circ}\right)$ from the direction of relative plate motions. To assess the implications of that issue, we have also compared our decomposition results to rotating block models that assume the direction of the subduction coupling component (given by the Juan de Fuca-North America relative plate motions) and the direction (but not the magnitude) of the block rotation (given by each block's rotation pole). We then decompose the observed GPS velocity field into these two directions-similar to how we did our decomposition.

The subduction components of the GPS velocity field in the model presented here and the block models (single and multi-block) are similar in magnitude (Additional file 1: Figure S5), with the main difference being (as noted above) in the orientation of the subduction component between relative plate motions and the orientation of the residual subduction component after removing rigid block motions (Additional file 1: Figure S6). In the rigid block case, in general, the direction of the subduction component is more eastward and varies significantly between and within blocks (Additional file 1: Figure S6). In our analyses we have found that north of $45^{\circ} \mathrm{N}$, the observed GPS velocity field is well described considering a subduction coupling signal alone (Fig. 2 and Additional file 1: Figure S1). Although the NNW-directed GPS component (from our decomposition) and the displacement direction of the blocks are similar in southern Cascadia (south of $45^{\circ} \mathrm{N}$ ) (Additional file 1: Figure S6), the block rotation models do not include internal deformation within blocks. This is inconsistent with geologic observations in southern Cascadia, including crustal thickening (Beaudoin et al. 1996; Beaudoin et al. 1988; Hayes and Furlong 2007), quaternary active faulting (Kelsey and Carver 1988) and high present-day and sustained geologic uplift rates (Burgette et al. 2009; Balco et al. 2013).

\section{Spatial variations in the subduction component}

The overall pattern of the subduction component of the GPS velocity field represents the characteristics (i.e., geometry and slip deficit) of Cascadia subduction coupling. The distance over which the velocities decrease in southern Cascadia, however, is shorter than in northern
Cascadia. This could be caused by several factors including a narrower coupled zone in southern Cascadia or alternatively different materials in the upper plate that accommodate inter-seismic deformation differently (McKenzie and Furlong 2020). The transition from a narrower to wider zone of decreasing velocities is at approximately $43^{\circ} \mathrm{N}$ and may also reflect one of several major changes in the subduction system. It coincides with a transition in the character of the down-going plate from south (Gorda) to north (Juan de Fuca) (Wilson 1989), a change in the geology of the upper plate from the Klamath terrane (south) to the Siletzia terrane (north), and changes in recent and current observations of upperplate uplift and exhumation (Burgette et al. 2009; Balco et al. 2013). Although there are some differences in the character of the upper plate and subducting plate, the dip of the plate interface stays relatively similar (to $\sim 35 \mathrm{~km}$ depth) across this transition (Hayes 2018).

\section{Permanent deformation driven by MCC/SNGV motions}

The systematic decrease in the magnitude of the NNWdirected component of the GPS velocity field in southwest Cascadia is indicative of a NNW-shortening strain with strain rates on the order of $10^{-14} \mathrm{~s}^{-1}$ (Fig. 4c). We expect that this pattern in the NNW-velocity field also continues offshore. This NNW-directed shortening strain in southwest Cascadia is consistent with the rates, areal extent and effects (crustal thickening and tectonic uplift) from the MCC process and coincides with the location of active quaternary faults (Kelsey and Carver 1988) and evidence for ongoing active uplift in the forearc (Burgette et al. 2009; Balco et al. 2013). The crustal thickness in this region (determined from seismicity, the depth to the plate interface and seismic tomography) increases from north to south along a SSE-striking profile towards the MTJ from $\sim 20 \mathrm{~km}\left(\right.$ at $\sim 42^{\circ} \mathrm{N}$ ) to $\sim 30 \mathrm{~km}$ at the MTJ (Furlong and Schwartz 2004). Further to the east, the SNGV block impinges on the Klamath terrane and the NNW-velocity component within the Klamath terrane remains relatively constant at $\sim 8-12 \mathrm{~mm} /$ year (Figs. $4 \mathrm{~b}$ and Additional file 1: S3). We interpret this to be a result of the Klamath terrane (primarily composed of plutonic and metamorphic rocks (Hotz 1971)) effectively behaving rigidly to the push on its southern boundary. The relatively high velocities of $8-12 \mathrm{~mm} /$ year within the Klamath terrane (comparable in magnitude to the SNGV motions; (Dixon et al. 2000)) suggest that MCC deformation may also be contributing to the motion of the Klamath terrane.

The steep slope seen in NNW velocities seen in the NEtrending profiles in southwest Cascadia and their flattening at the boundary to the Klamath terrane (Fig. 4b) suggests localized right-lateral strain adjacent to the terrane. This slope change is a result of MCC displacements 
being greater (i.e., producing higher upper-plate velocities) in southern Cascadia than the SNGV block to its east. The location of this slope change corresponds to several (active) NNW-trending right-lateral strike-slip faults/fault zones within the upper plate, including the Grogan fault, the Lost Man fault, and the Bald Mountain fault zone (Fig. 1) (Kelsey and Carver 1988).

\section{Signature of competing tectonic processes}

The NNW component of the observed GPS velocity field in southwest Cascadia produces a NNW-directed shortening strain in the upper plate (shown by the rapid decrease in velocities from south to north (Fig. 4c)). Although there is shallow background seismicity ( $\mathrm{Mw}$ 2.5-5) within the upper plate in southern Cascadia, any significant (>Mw 5) seismicity within the southern Cascadia subduction zone appears to be at depths consistent with being within the subducting plate, and not in the upper plate or along the plate interface (Additional file 1: Figure S7). This means we cannot easily use the present-day earthquake record in this region to evaluate strain. However, there are many Quaternary active structures in this region that record a relatively complex strain pattern. There are several upper plate trench-parallel reverse faults (i.e., the northern Little Salmon fault (LSF) and Mad River fault zone (Fig. 1)) and folds within southwest Cascadia, mapped both onshore and offshore (Kelsey and Carver 1988; McCrory 2000), that similar to other subduction zones, record permanent (albeit small) subduction earthquake cycle upper-plate deformation. Other structures within southwest Cascadia, for example the Russ and Capetown faults (Fig. 1), show evidence for both strike-slip and reverse faulting, implying that multiple tectonic regimes may act in the region (Kelsey and Carver 1988). To the east of the Russ and Capetown faults is the LSF, an approximately NW striking low-angle reverse fault. The northern section of the LSF trends NNW, whereas its southern section trends NW, indicating that the fault is potentially responding to competing tectonic processes. Adjacent and sub-parallel to the LSF is the Goose Lake fault that has evidence of right-lateral strike-slip motion (Ladinsky et al. 2019; Bold et al. 2020).

As well as active faulting, there is significant uplift in southern Cascadia that has been sustained over the Quaternary (Balco et al. 2013). Present-day (geodetic) rates of uplift in southern Cascadia are $\sim 1-4 \mathrm{~mm} /$ year along the coastline from the MTJ to $\sim 43^{\circ} \mathrm{N}$ (Fig. 1) (Burgette et al. 2009; Blewitt et al. 2018). Marine terrace uplift rates during the Quaternary across Cascadia record higher uplift rates in southern Cascadia $(\sim 0.25 \mathrm{~mm} /$ year, $6-25 \%$ of the present-day geodetic uplift signal) compared with central Cascadia $(\sim 0.1 \mathrm{~mm} /$ year, $<10 \%$ of the present-day geodetic uplift signal) (Kelsey et al. 1994). The near-coastal region of southern Cascadia from the MTJ to $\sim 43^{\circ} \mathrm{N}$ is also characterized by high elevations, high relief (Fig. 1), high channel steepness indices and high basin average erosion rates compared to the region of Cascadia to the north (Balco et al. 2013; Worms et al. 2020; Kirby et al. 2020). These observations all indicate a landscape that is experiencing sustained uplift. This is in conflict with most subduction cycle models, which indicate that the coastline located above or near the locked patch(es) of a subduction zone subsides during the inter-seismic period (e.g., Govers et al. 2018). Typically, this inter-seismic subduction earthquake cycle subsidence would be (largely) recovered by co-seismic and post-seismic vertical motions over multiple subduction earthquake cycles. The permanent uplift observed in southern Cascadia, localized to the forearc region that is also experiencing NNW-shortening related to the MCC, likely reflects the combination of permanent NNW-shortening with small amounts of un-recovered subduction-related shortening within the upper plate, west of the Klamath terrane (McKenzie and Furlong 2020).

\section{Migration of the MTJ and SNGV over 6 million years}

The GPS velocity field records a snapshot of present-day deformation; however, MCC shortening and the SNGV block are and have been migrating northward over the last 6 million years. This leads to an evolution in the tectonics of southern Cascadia. To determine how this migrating plate boundary has affected deformation in southern Cascadia, we reconstruct plate tectonic interactions over the last 6 million years (Figs. 5 and 6). At $6 \mathrm{Ma}$, the MTJ and its associated region of active crustal shortening (migrating to the north at $\sim 50 \mathrm{~km} / \mathrm{Myr}$ (Furlong and Govers 1999; Lock et al. 2006)) would have been approximately $300 \mathrm{~km}$ south of their current location (Fig. 5). Therefore, at $6 \mathrm{Ma}$, locations currently in southern Cascadia would have experienced deformation dominated largely by NE-directed subduction coupling effects. From $\sim 6 \mathrm{Ma}$ to present, with the increasing addition of the MCC-driven NNW motions, GPS velocities (a proxy for deformational conditions) in southern Cascadia will have undergone a counter-clockwise rotation (Fig. 5). In the future, as the MTJ and SNGV block continue to migrate northward, the North America upper plate in southern Cascadia will transfer from the Cascadia subduction zone to become part of the San Andreas plate boundary system.

Evidence for such a deformation field that initially records subduction deformation followed by a combination of NE-and NNW-shortening (and some right-lateral translation) (Figs. 5 and 6), that later becomes purely right-lateral, is preserved in the faulting history south of the MTJ (Kelsey and Carver 1988). The NNW-striking 


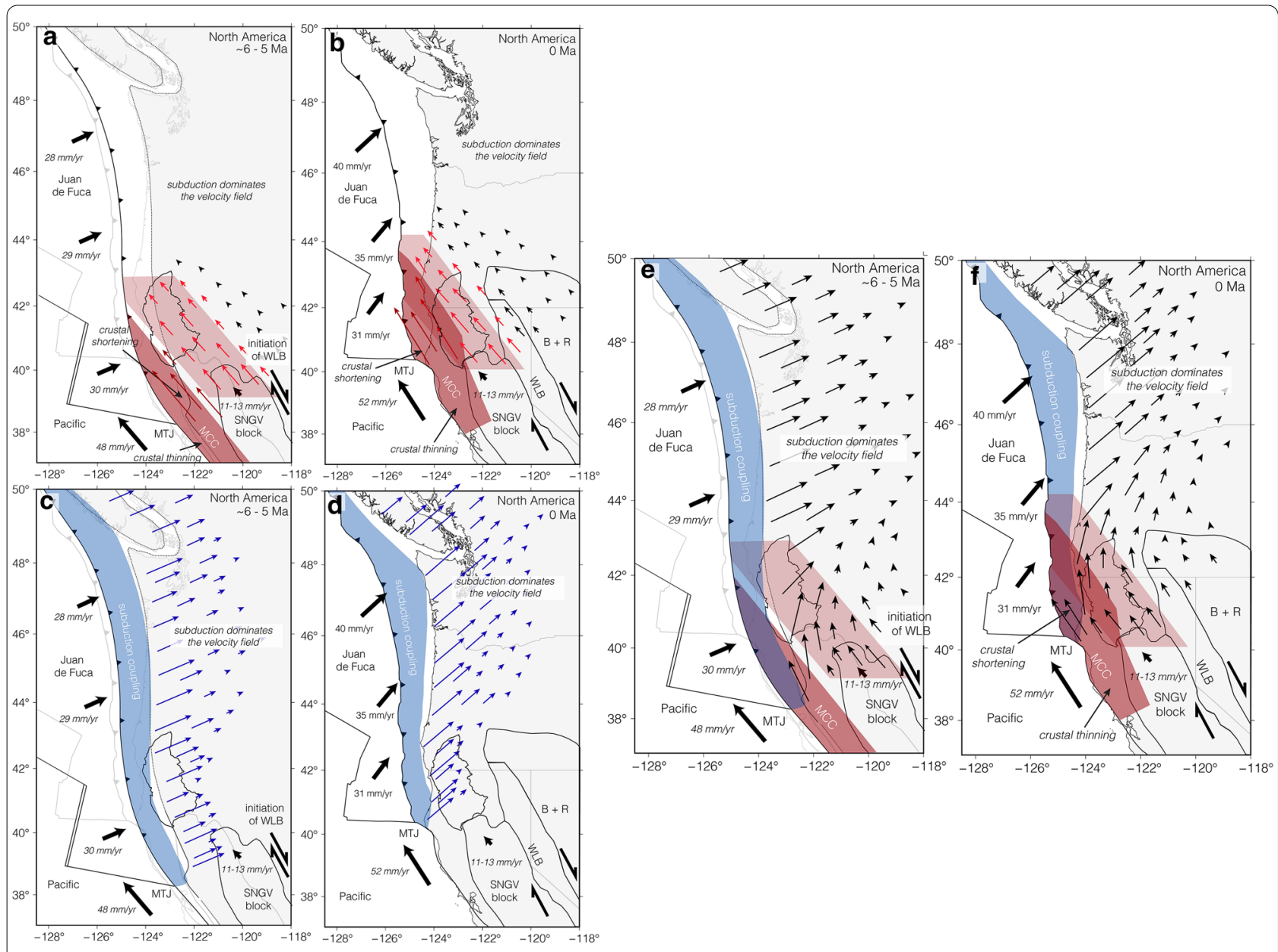

Fig. 5 Paleo-reconstruction of the plate boundary system across Cascadia, including the region south of the MTJ using finite rotation poles from DeMets and Merkouriev (2016) and Wilson (1993) — the methodology is described in the supporting material. The paleo-shorelines shown in the 6-5 Ma reconstructions are interpolated from Lock et al. (2006). a 6-5 Ma reconstruction showing the approximate location of the MCC and SNGV deformational footprints and a schematic paleo-(NNW component)-GPS field based on reconstructed plate motions. b Present-day map of the Cascadia plate boundary system showing the approximate location of the MCC and SNGV deformational footprints (based on results from this study) and a schematic of the observed NNW component of the GPS field. c 6-5 Ma reconstruction showing the approximate location of the subduction-related deformational footprint and a schematic paleo-(subduction component)-GPS field based on reconstructed plate motions. $\mathbf{d}$ Present-day map of the Cascadia plate boundary system showing the approximate location of the subduction coupling deformational footprints and a schematic of the observed subduction component of the GPS field. e $\sim 6-5$ Ma reconstruction showing the approximate location of the subduction, MCC and SNGV deformational footprints and a schematic total paleo-GPS field based on reconstructed plate motions. $\mathbf{f}$ Present-day map of the Cascadia plate boundary system showing the approximate location of the subduction, MCC and SNGV deformational footprints and a schematic of the observed total GPS field

Dean Creek and Temblor faults (Figs. 1 and 6), both located south of the present-day MTJ, record low-angle reverse faulting of Franciscan basement above Neogene units (Kelsey and Carver 1988); however, the lack of Quaternary offset across these reverse faults suggests they may no longer be active. Sub-parallel to the Dean Creek and Temblor faults are the Garberville and Lake Mountain fault zones (Figs. 1 and 6) that accommodate right-lateral motion. In particular right-lateral offsets of the Coastal Belt Thrust (across the Garberville fault zone) imply right-lateral motion post-dates contraction.
Similarly, right-lateral faulting within the Lake Mountain fault zone offsets the Temblor fault (that records earlier reverse motion). These observations of recent right-lateral strike-slip faulting that post-date low-angle thrust faulting are evidence for an evolving tectonic regime that was first dominated by NE-SW shortening, assumed to be associated with subduction coupling, followed by NNWtrending right-lateral translation. Although this rightlateral faulting occurs within the San Andreas transform plate boundary, the region of right-lateral strain accumulation at the western boundary of the Klamath terrane 


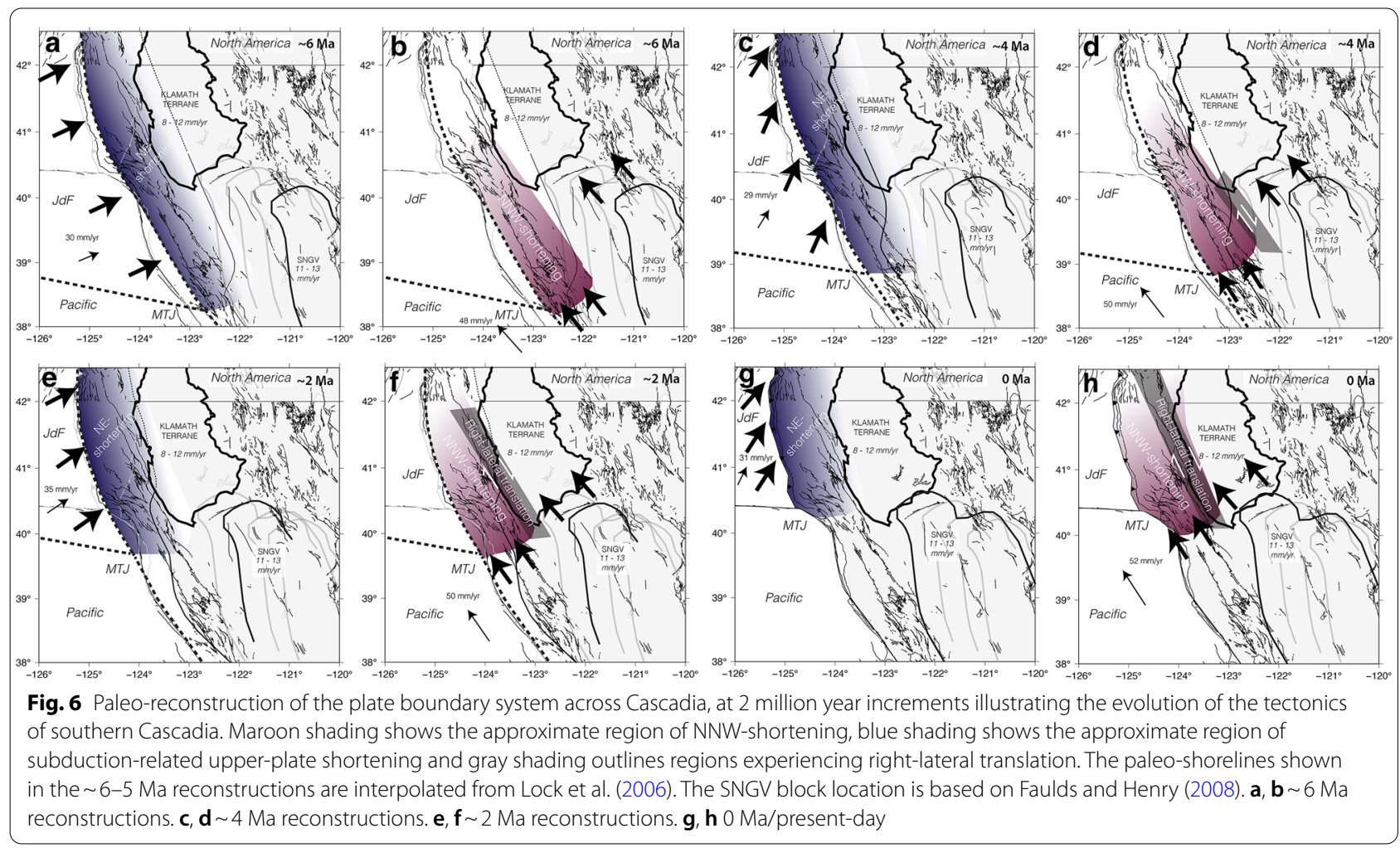

(identified here (Figs. 4c and 6)), suggests the initiation of right-lateral motion on (and the development of) these faults may have initiated prior to passage of the MTJ. At present, several right-lateral strike-slip faults (including the Grogan Fault) appear to be accommodating this right-lateral motion north of the MTJ.

This evolution in the tectonics of southern Cascadia with the migration of the MTJ and SNGV block has implications for how we interpret geologic observations. For example, one piece of geologic evidence used in support of the rigid upper-plate rotation is the observed paleomagnetic rotations within Cascadia (Wells and McCaffrey 2013). Present-day block rotation rates of $\sim 1^{\circ} \%$ Myear (McCaffrey et al. 2007), combined with total observed paleomagnetic rotations imply a $\sim 16 \mathrm{Ma}$ duration to the block rotations. However, since the MTJ was substantially further south (as recently as 5-6 Ma), and if it (and the SNGV block) are important in driving the translation/rotation of the coastal blocks, then this block rotation would have also migrated northward through time. This is inconsistent with the duration of rotation recorded by paleomagnetic data (of $\sim 16 \mathrm{Ma}$ ) and so paleomagnetic data may instead reflect local vertical axis rotations, for example from variable shortening rates across upper-plate trench-perpendicular strike-slip faults and/or variations in coupling on the subduction interface. It should also be noted that the direction of motion of a location in the Cascadia forearc undergoes a counter-clockwise rotation over time as a consequence of the migration of the MTJ and SNGV block.

\section{Active tectonics driven by Klamath terrane motions}

Our results indicate that at present the Klamath terrane is effectively behaving as a rigid block in response to subduction coupling and NNW-striking tectonic forces. As a result it is translating to the NNW (at $\sim 8-12 \mathrm{~mm} /$ year) with little internal deformation. The lack of present-day seismicity (Additional file 1: Figure S7) and internal deformation with the Klamath terrane is consistent with results from Piotraschke et al. (2015) which showed that the primary uplift (seen in rapid exhumation) of the Klamath terrane occurred during two periods of exhumation in the Late Cretaceous-Paleocene and the Oligocene-Miocene. Although the landscape of the Klamath terrane shows current adjustments and crustal thicknesses of $\sim 35-40 \mathrm{~km}$ (Liu et al. 2012; Beaudoin et al. 1996), the overall high elevations of the terrane appear to be a middle to late Miocene feature. In contrast, NW of the Klamath terrane is a region of high geodetic uplift rates (Fig. 1) ( 1-4 mm/year (Burgette et al. 2009; Blewitt et al. 2018)), high basin average erosion rates (Balco et al. 2013), high relief (Fig. 1b), high normalized channel 
steepness indices (Kirby et al. 2020; Worms et al. 2020) and crustal thicknesses of 25-35 km (Porritt et al. 2011; Delph et al. 2021). Since the SNGV block has moved significantly less than the MTJ over the past 6 million years, SNGV-related tectonic forcing reached the Klamath terrane region prior to MCC-related deformation (Figs. 5 and 6), suggesting that shortening in this region $\mathrm{NW}$ of the Klamath terrane may have begun at 3-4 Ma, and then accelerated once the footprint of MCC-related deformation reached the region (Fig. 6). This implies that the relatively high topography and relief that makes up the Siskiyou Mountains developed and began eroding significantly over the last few million years.

\section{Conclusions}

Several tectonic processes (subduction coupling, the MCC effect and SNGV block northward motion) are deforming the Cascadia upper plate and their superposition is seen in both the present-day GPS velocity field and the geologic record. We have found that north of $\sim 45^{\circ} \mathrm{N}$, at present, subduction coupling is the principal driver of upper-plate deformation. However, south of $\sim 45^{\circ} \mathrm{N}$, the MCC effect and northward motion of the SNGV block have a significant influence on upper-plate deformation. The superposition of NNW-trending tectonic drivers on the subduction coupling signal produces an apparent clockwise rotation in the GPS velocity field north of the MTJ to $\sim 45^{\circ} \mathrm{N}$. Consistent with MCC model results, the NNW component of the GPS velocity field shows significant NNW-shortening in SW Cascadia. In contrast, the NNW motion of the SNGV block (combined with the MCC effect) appears to be "pushing" the Klamath terrane rigidly and causing both localized shortening along its northwest boundary and right-lateral strain across its western boundary.

\section{Abbreviations}

GPS: Global Positioning System; MTJ: Mendocino Triple Junction; MCC: Mendocino crustal conveyor; SNGV: Sierra Nevada-Great Valley; nECSZ-WL: northern Eastern California Shear Zone-Walker Lane.

\section{Supplementary Information}

The online version contains supplementary material available at https://doi. org/10.1186/s40562-021-00181-z.

Additional file 1. Supplementary Information File (supplemental text, Figures S1-S7, Table S1).

\section{Acknowledgements}

We would like to thank the National Science Foundation who provided support for this research under the Award EAR175781. We thank Dr. Eric Kirby and Dr. Matthew Herman who contributed scientific discussion that helped improved the manuscript. We also thank two anonymous reviewers for providing reviews that helped us improve the manuscript.

\section{Authors' contributions}

KAM analyzed the GPS data; KAM and KPF interpreted the results; KAM was the main contributor in writing the manuscript; KAM and KPF both edited final manuscript. Both authors read and approved the final manuscript.

\section{Funding}

The National Science Foundation who provided support for this research under the Award EAR175781.

\section{Availability of data and materials}

The MIDAS GPS velocity data used in this study are from the Nevada Geodetic Laboratory (http://geodesy.unr.edu/, Blewitt et al. 2018). The SRTM digital elevation model (Farr et al. 2007, https://doi.org/10.1029/2005RG000183) used in Fig. 1 was sourced from OpenTopography (https://portal.opentopography. org/datasets). The block boundaries and rotation poles used to produce Additional file 1: Figure S6 are from the published article McCaffrey et al. (2007) (https://doi.org/10.1111/j.1365-246X.2007.03371.x). The finite reconstruction poles used to create Figs. 5 and 6 are from the published articles Wilson (1993) and DeMets and Merkouriev (2016). Maps were produced using GMT (https:// www.generic-mapping-tools.org/; Wessel et al. 2019).

\section{Declarations}

\section{Competing interests}

The authors declare that they have no competing interests.

Received: 15 December 2020 Accepted: 19 March 2021

Published online: 31 March 2021

\section{References}

Argus DF, Gordon RG (1991) Current Sierra Nevada-North America motion from very long baseline interferometry: implications for the kinematics of the western United States. Geology 19:1085-1088. https://doi.org/10. 1130/0091-7613(1991)-19\%3c1085:CSNNAM\%3e2.3.CO;2

Balco G, Finnegan N, Gendaszek A, Stone JOH, Thompson N (2013) Erosional response to northward-propagating crustal thickening in the coastal ranges of the U.S. Pacific Northwest. AJS 313(8):790-806. https://doi.org/ 10.2475/11.2013.01

Beaudoin BC, Godfrey NJ, Klempetet SL, Lendl C, Tréhu AM, HenstockTJ, Levander A, Holl JE, Meltzer AS, Luetger JH, Mooney WD (1996) Transition from slab to slabless: results from 1993 Mendocino triple junction seismic experiment. Geology 24(3):195-199. https://doi.org/10.1130/00917613(1996)024\%3c0195:TFSTSR\%3e2.3.CO;2

Beaudoin BC, Hole JA, Klemperer SL, Tréhu AM (1998) Location of the southern edge of the Gorda slab and evidence for an adjacent asthenospheric window: results from seismic profiling and gravity. Papers Seismol 103(B12):30101-30115. https://doi.org/10.1029/98JB02231

Bennett RA, Wernicke BP, Niemi NA, Friedrich AM, Davis JL (2003) Contemporary strain rates in the northern Basin and Range province from GPS data. Tectonics. https://doi.org/10.1029/2001TC001355

Bennett GL, Miller SR, Roering JJ, Schmidt DA (2016) Landslides, threshold slopes, and the survival of relict terrain in the wake of the Mendocino Triple Junction. Geology 44(5):363-366. https://doi.org/10.1130/G37530.1

Blewitt G, Hammond WC, Kreemer C (2018) Harnessing the GPS data explosion for interdisciplinary science. Eos. https://doi.org/10.1029/2018E 0104623

Bold, SE, Michalak MJ, Ladinsky T, Kelsey HM, Patton JR, Blisniuk K (2020) Tectonic History at the Mendocino Triple Junction: Quaternary Mapping of the Goose Lake Fault, Van Duzen River Terraces, and Yager Creek Terraces, Humboldt County, California. Paper presented at GSA 2020 Connects Online, 26-30 Oct 2020.

Burgette RJ, Weldon RJ II, Schmidt DA (2009) Interseismic uplift rates for western Oregon and along-strike variation in locking on the Cascadia subduction zone. JGR Solid Earth. https://doi.org/10.1029/2008JB005679

Cashman SM, Kelsey HM, Erdman CF, Cutten HNC, Berryman KR (1992) Strain Partitioning between structural domains in the forearc of the Hikurangi Subduction Zone, New Zealand. Tectonics 11(2):242-257. https://doi.org/ 10.1029/91TC02363 
Delph JR, Thomas AM, Levander A (2021) Subcretionary tectonics: linking variability in the expression of subduction along the Cascadia forearc. EPSL. https://doi.org/10.1016/j.epsl.2020.116724

DeMets C, Merkouriev S (2016) High-resolution reconstructions of Pacific North America plate motion: 20 Ma to present. Geophys J Int 207(2):741773. https://doi.org/10.1093/gji/ggw305

DeMets C, Gordon RG, Argus DF (2010) Geologically current plate motions. Geophys J Int 181(1):1-80. https://doi.org/10.1111/j.1365-246X.2009. 04491.x

Dixon TH, Miller M, Farina F, Wang H, Johnson D (2000) Present-day motion of the Sierra Nevada block and some tectonic implications for the Basin and Range province North American Cordillera. Tectonics 19(1):1-24. https:// doi.org/10.1029/1998TC001088

Farr TG, Rosen PA, Caro E, Crippen R, Duren R, Hensley S, Kobrick M, Paller M, Rodriguez E, Roth L, Seal D, Shaffer S, Shimada J, Umland J, Werner M, Oskin M, Burbank D, Alsdorf D (2007) The Shutter Radar Topography Mission. Rev Geophys. https://doi.org/10.1029/2005RG000183

Faulds JE, Henry CD (2008) Tectonic influences on the spatial and temporal evolution of the Walker Lane: An incipient transform fault along the evolving Pacific - North America plate boundary. In: Spencer JE, Titley SR (eds) Ores and orogenesis: Circum-Pacific tectonics, geologic evolution and ore deposits: Arizona Geological Society Digest 22:437-470.

Furlong KP (1984) Lithospheric behavior with triple junction migration: an example based on the Mendocino Triple Junction. Phys Earth Planet Int 36(3-4):213-223. https://doi.org/10.1016/0031-9201(84)90047-5

Furlong KP, Govers R (1999) Ephemeral crustal thickening at a triple junction: the Mendocino crustal conveyor. Geology 27(2):127-130. https://doi.org/ 10.1130/0091-7613(1999)027\%3c0127:ECTAAT\%3e2.3.CO;2

Furlong KP, Schwartz SY (2004) Influence of the Mendocino triple junction on the tectonics of Coastal California. Annu Rev Earth Planet Sci 32:403-433. https://doi.org/10.1146/annurev.earth.32.101802.120252

Furlong KP, Lock J, Guzofski C, Whitlock J, Benz H (2003) The Mendocino Crustal Conveyor: making and breaking the California Crust. Int Geol Rev 45(9):767-779. https://doi.org/10.2747/0020-6814.45.9.767

Govers R, Furlong KP, van de Wiel L, Herman MW, Broerse T (2018) The geodetic signature of the earthquake cycle at subduction zones: model constraints on the deep processes. Rev Geophys 56(1):6-49. https://doi.org/10.1002/ 2017RG000586

Hayes G (2018) Slab2 - A Comprehensive Subduction Zone Geometry Model: U.S. Geological Survey data release. https://doi.org/10.5066/F7PV6JNV

Hayes GP, Furlong KP (2007) Abrupt changes in crustal structure beneath the Coast Ranges of northern California - developing new techniques in receiver function analysis. Geophys J Int 170(1):313-336. https://doi.org/ $10.1111 / j .1365-246 X .2007 .03401 . X$

Hotz PE (1971) Plutonic rocks of the Klamath Mountains, California and Oregon. USGS Numbered Series Professional Paper 684(B). https://doi. org/10.3133/pp684B

Kelsey HM, Carver GA (1988) Late Neogene and Quaternary tectonic associated with northward growth of the San Andreas Transform Fault, northern California. JGR Solid Earth 93(B5):4797-4819. https://doi.org/10.1029/ JB093iB05p04797

Kelsey HM, Engebretson DC, Mitchell CE, Ticknor RL (1994) Topographic form of the Coast Ranges of the Cascadia Margin in relation to coastal uplift rates and plate subduction. JGR Solid Earth 99(B6):12245-12255. https:// doi.org/10.1029/93JB03236

Kirby E, Furlong KP, Von Dassow W, Worms K, McKenzie K, Mahan SA (2020) Does Topography Along the Cascadia Forearc Reflect Permanent Deformation of North America? Paper presented at GSA 2020 Connects Online, 26-30 Oct 2020.

LaFemina P, Dixon TH, Govers R, Norabuena E, Turner H, Saballos A, Mattioli G, Protti M, Strauch W (2009) Fore-arc motion and Cocos Ridge collision in Central America. Geochem Geophys Geosyst. https://doi.org/10.1029/ 2008GC002181

Ladinsky TC, Kelsey HM, Bold S, Michalak M, Witter RC (2019) Investigating Fault Rupture Connectivity Between Upper-plate Faults and the Southern Cascadia Subduction Zone: A Paleoseismic Investigation of the Little Salmon Fault Zone, Hydesville, California. Paper presented at the AGU Fall Meeting 2019, San Francisco, CA, 9-13 Dec, 2019

Liu K, Levander A, Zhai Y, Porritt R, Allen RM (2012) Asthenospheric flow and lithospheric evolution near the Mendocino triple junction. EPSL 323-324:60-71. https://doi.org/10.1016/j.epsl.2012.01.020
Lock J, Kelsey H, Furlong K, Woolace A (2006) Late Neogene and Quaternary landscape evolution of the northern California Coast Ranges: evidence for Mendocino triple junction tectonics. GSA Bull 118(9/10):1232-1246. https://doi.org/10.1130/B25885.1

Manaker DM, Calais E, Freed AM, Ali ST, Przybylski P, Mattioli G, Jansma P, Prépetit C, De Chabalier JB (2008) Interseismic plate coupling and strain partitioning in the Northeastern Caribbean. Geophys J Int 174(3):889903. https://doi.org/10.1111/j.1365-246X.2008.03819.x

McCaffrey R (2005) Block kinematics of the Pacific-North America plate boundary in the southwestern United States from inversion of GPS, seismological and geologic data. JGR Solid Earth. https://doi.org/10.1029/2004J B003307

McCaffrey R, Zwick PC, Bock Y, Prawirodirdjo L, Genrich JF, Stevens CW, Puntodewo SSO, Subarya C (2000) Strain partitioning during oblique plate convergence in northern Sumatra: geodetic and seismological constraints and numerical modeling. JGR Solid Earth 105(B12):28363-28376. https://doi.org/10.1029/1999JB00362

McCaffrey R, Qamar Al, King RW, Wells R, Khazaradze G, Williams CA, Stevens CW, Vollick JJ, Zwick PC (2007) Fault locking, block rotation and crustal deformation in the Pacific Northwest. Geophys J Int 169(3):1315-1340. https://doi.org/10.1111/j.1365-246X.2007.03371.x

McCaffrey R, King RW, Payne SJ, Lancaster M (2013) Active tectonics of northwestern U.S. inferred from GPS-derived surface velocities. JGR Solid Earth 118(2):709-723. https://doi.org/10.1029/2012JB009473

McCrory PA (2000) Upper plate contraction north of the migrating Mendocino triple junction, northern California: Implications for partitioning of strain. Tectonics 19(6):1144-1160. https://doi.org/10.1029/1999TC001177

McKenzie KA, Furlong KP (2020) What is Causing (Permanent) Uplift in Southern Cascadia? Paper presented at the AGU Fall Meeting 2020, online everywhere, 1-17 Dec 2020.

McKenzie KA, Furlong KP, Herman MW (2020) Bidirectional loading of the subduction interface: evidence from the kinematics of slow slip events. Geochem Geophys Geosyst. https://doi.org/10.1029/2020GC008918

McQuarrie N, Wernicke BP (2005) An animated tectonic reconstruction of southwestern North America since $36 \mathrm{Ma}$. Geosphere 1(3):147-172. https://doi.org/10.1130/GES00016.1

Morell KD, Kirby E, Fisher DM, van Soest M (2012) Geomorphic and exhumational response of the Central American Volcanic Arc to Cocos Ridge Subduction. JGR Solid Earth. https://doi.org/10.1029/2011JB008969

Moreno M, Li S, Melnick D, Bedford JR, Baez JC, Motagh M, Metzger S, Vajedian S, Sippl C, Gutknecht BD, Contreras-Reyes E, Deng Z, Tassara A, Oncken O (2018) Chilean megathrust earthquake recurrence linked to frictional contrast at depth. Nat Geosci 11:285-290. https://doi.org/10.1038/ s41561-018-0089-5

Piotraschke R, Cashman SM, Furlong KP, Kamp PJJ, Danišík M, Xu G (2015) Unroofing the Klamaths - Blame it on Siletzia? Lithosphere 7(4):427-440. https://doi.org/10.1130/L418.1

Plattner C, Malservisi R, Furlong FP, Govers R (2010) Development of the Eastern California Shear Zone - Walker Lane belt: The effects of microplate motion and pre-existing weakness in the Basin and Range. Tectonophysics 485:78-84. https://doi.org/10.1016/j.tecto.2009.11.021

Porritt RW, Allen RM, Boyarko DC, Brudzinski MR (2011) Investigation of Cascadia segmentation with ambient noise tomography. EPSL 309(1-2):67-76. https://doi.org/10.1016/j.epsl.2011.06.026

Roering JJ, Mackey BH, Handwerger AL, Booth AM, Schmidt DA, Bennett GL, Cerovski-Darriau C (2015) Beyond the angle of repose: a review and synthesis of landslide processes in response to rapid uplift, Eel River, Northern California. Geomorphology 236:109-131. https://doi.org/10. 1016/j.geomorph.2015.02.013

Rogers G, Dragert H (2003) Episodic tremor and slip on the Cascadia subduction zone: the chatter of silent slip. Science 300(5627):1942-1943. https:// doi.org/10.1126/science.1084783

Satake K (2015) Geological and historical evidence of irregular recurrent earthquakes in Japan. Phil Trans R Soc A 373(2053):20140375. https://doi. org/10.1098/rsta.2014.0375

Savage JC, Svarc JL, Prescott WH, Murray MH (2000) Deformation across the forearc of the Cascadia subduction zone at Cape Blanco. Oregon JGR Solid Earth 105(B2):3095-3102. https://doi.org/10.1029/1999JB900392

USGS (U.S. Geological Survey), Quaternary fault and fold database for the United States, accessed Dec 14 2020, at: https://www.usgs.gov/naturalhazards/earthquake-hazards/faults 
Wells RE, McCaffrey R (2013) Steady rotation of the Cascade arc. Geology 41(9):1027-1030. https://doi.org/10.1130/G34514.1

Wells RE, Weaver CS, Blakley RJ (1998) Forearc migration in Cascadia and its neotectonics significance. Geology 26(8):759-762. https://doi.org/10. 1130/0091-7613(1998)026\%3c0759:FAMICA\%3e2.3.CO;2

Wells RE, Blakely RJ, Wech AG, McCrory PA, Michael A (2017) Cascadia subduction tremor muted by crustal faults. Geology 45(6):515-518. https://doi. org/10.1130/G38835.1

Wilson DS (1989) Deformation of the so-called Gorda Plate. JGR Solid Earth 94(B3):3065-3075. https://doi.org/10.1029/JB094iB03p03065

Wilson DS (1993) Confidence intervals for motion and deformation of the Juan de Fuca Plate. JGR Solid Earth 98(B9):16053-16071. https://doi.org/10. 1029/93JB01227
Worms K, Kirby E, Bierman P, Corbett LB, Jungers M (2020) Evaluating Spatial Variation in Topography and Erosion Rate Along the Cascadia Forearc. Paper presented at GSA 2020 Connects Online, 26-30 Oct 2020.

\section{Publisher's Note}

Springer Nature remains neutral with regard to jurisdictional claims in published maps and institutional affiliations.

\section{Submit your manuscript to a SpringerOpen ${ }^{\circ}$ journal and benefit from:}

- Convenient online submission

- Rigorous peer review

- Open access: articles freely available online

- High visibility within the field

- Retaining the copyright to your article

Submit your next manuscript at $\boldsymbol{\nabla}$ springeropen.com 